\title{
MODELING OF IRON ORE REACTIONS IN BLAST
}

\section{FURNACE}




\begin{abstract}
Iron ore (pellet, sinter and lump ore) is gradually reduced to iron in blast furnace. The reductions are a serial of heterogeneous gas solid reactions that take place from the top of the furnace and throughout the shaft region of the furnace. Two major categories of iron ore reaction model had been developed and applied for modeling the iron ore reduction: Un-Reacted shrinking Core (URC) model and grain model. The URC model had been widely adopted in blast furnace numerical model due to its simplicity for numerical implementation. However, the URC model assumes the reaction taking place in a sharp interface inside the iron ore. The sharp interface assumption may not be valid in the entire reaction stage due to the porous natural of the iron ore. The grain model was proposed to overcome such limitation. But the complexity of the grain model restricts its application to single ore granule reaction process and it has not been applied full blast furnace modeling. In this paper, a novel methodology is proposed to implement the grain model to predict iron ore reduction in blast furnace. The model considers the gas diffusion in porous iron ore, the dynamic composition changes of iron ore along the radius of the iron ore, the iron ore transport in blast furnace. The gas flow and interphase heat transfer are also considered. The result reveals the detailed heat and mass transfer process for the iron ore reduction in blast furnace shaft.
\end{abstract}

Keywords: blast furnace, iron ore reduction, CFD, grain model, Un-reacted shrinking core model 


\section{Introduction}

Iron ore (pellet, sinter and lump) is gradually reduced to iron in blast furnace. The reductions are a serial of heterogeneous gas solid reactions that take place from the top of the furnace and throughout the shaft region of the furnace. For full blast furnace numerical modeling, the accurate prediction of the reaction kinetics is essential as the reaction rates will be used as the source term for the conservation equations in the blast furnace computational fluid dynamics (CFD) model. The overall reaction rate of a single ore will be determined by the total resistance generated by following general steps [1]. (i) gas film resistance: mass transfer of gaseous reactant from the bulk flow to the ore surface; (ii) production layer resistance: diffusion of the gaseous reactant through the porous reduced solid layer; (iii) intrinsic chemical resistance: chemical reaction resistance between the metal-oxide and the gaseous reactant.

Depending on the iron ore porosity, two major categories of models have been developed and applied for modeling the iron ore reduction: Un-Reacted shrinking Core (URC) model [1, 2] and grain model $[3,4]$. The basic assumption of the URC model is that the chemical reaction only takes places in a sharp interface between the reacted and unreacted zone. The one interface [5] and three interfaces [6] URC models are the most frequently used ore reduction model in the blast furnace modeling. However, the assumptions of the URC model are valid in the two following situations. The first situation is that the URC model can be used to predict the reduction process of dense pellet, i.e., the gaseous reactant is restricted in the reaction interface. Second situation is that the URC model is also applicable when the intrinsic chemical resistance 
MODELING OF IRON ORE REACTIONS IN BLAST FURNACE SHAFT

is negligibly small, i.e., the chemical reaction is much faster than the gas diffusion in the production layer.

The grain model is proposed to overcome the limitation of the URC model. The grain model allows the chemical reaction and gaseous diffusion proceeds simultaneously in iron ore composed of small grains. The reaction takes place in the volumetric region rather than being constrained to a sharp interface. Therefore, the reaction rate varies locally along the radius of the ore. The additional resistance may also be considered due to the diffusion of the solid product layer for each individual grain [3]. Unlike the URC model, the analytical solution for the grain model is usually unavailable, thus the discretization along the ore radius is required to apply the grain model to blast furnace numerical method in a moving bed fashion. Therefore, the grain model has been limited to apply to single ore reduction in batch furnace or fixed beds reduction $[3,4]$. Recently, blast furnace numerical models in one-dimension [7, 8], two-dimensions [9, 10 and 11] and three-dimensions [12, 13] have been developed extensively. However, all the aforementioned blast furnace models implement the URC model for iron ore reduction. The difficulty to implement grain model in blast furnace is mainly because that discretization along the ore radius in a moving bed fashion is required. In this paper, a novel method is developed to incorporate the grain model in to the blast furnace model. This novel method not only applies to the iron ore reduction in blast furnace but also suits for the general moving bed reduction system such as shaft furnace. In addition, the URC model and grain model in blast furnace modeling are compared. 
MODELING OF IRON ORE REACTIONS IN BLAST FURNACE SHAFT 


\section{Numerical Model}

\subsection{Iron Ore Reaction in Blast Furnace Shaft}

The reduction of iron ore proceeds via the successive steps $\mathrm{Fe}_{2} \mathrm{O}_{3} \rightarrow \mathrm{Fe}_{3} \mathrm{O}_{4} \rightarrow \mathrm{FeO} \rightarrow \mathrm{Fe}$ in blast furnace. This paper is based on the framework of the blast furnace numerical model developed previously $[11,14]$. The focus of the present study is to implement the grain model into the blast furnace model and compare with the URC model. As listed in 
Table 1, the two different models, i.e., URC and grain, have been applied to the indirect reduction of the iron ore by $\mathrm{CO}$ and $\mathrm{H}_{2}$ as listed in 
Table 1 R1-R6. Other reactions such as the coke reactions (Boudouard reaction, water gas reaction), flux decomposing, water gas shift reaction, direct reduction of $\mathrm{FeO}$ are also considered. Blast furnace coke undergoes three main reactions in the shaft. These are the Boudouard reaction (7), the water-gas reaction (8) and the direct reduction reaction $(\mathrm{C}+\mathrm{FeO}=\mathrm{Fe}+\mathrm{CO})$ which is, kinetically, a combination of reaction (3) and reaction (7) or a combination of reaction (6) and reaction (8). The detail description of the models for other reactions is published elsewhere $[14$, 21]. 
Table 1. Chemical reactions considered in the CFD model

\begin{tabular}{|l|l|l|l|}
\hline Reaction & No. & Chemical Equation & Rate \\
\hline $\begin{array}{l}\text { Indirect } \\
\text { Reduction by CO }\end{array}$ & $\mathrm{R}-1$ & $3 \mathrm{Fe}_{2} \mathrm{O}_{3}(\mathrm{~s})+\mathrm{CO}(\mathrm{g}) \rightarrow 2 \mathrm{Fe}_{3} \mathrm{O}_{4}(\mathrm{~s})+\mathrm{CO}_{2}(\mathrm{~g})$ & $\mathrm{R}_{1}$ \\
\cline { 2 - 4 } & $\mathrm{R}-2$ & $\mathrm{Fe}_{3} \mathrm{O}_{4}(\mathrm{~s})+\mathrm{CO}(\mathrm{g}) \rightarrow 3 \mathrm{FeO}(\mathrm{s})+\mathrm{CO}_{2}(\mathrm{~g})$ & $\mathrm{R}_{2}$ \\
\cline { 2 - 5 } & $\mathrm{R}-3$ & $\mathrm{FeO}(\mathrm{s})+\mathrm{CO}(\mathrm{g}) \rightarrow \mathrm{Fe}(\mathrm{s})+\mathrm{CO}_{2}(\mathrm{~g})$ & $\mathrm{R}_{3}$ \\
\hline $\begin{array}{l}\text { Indirect } \\
\text { Reduction by } \mathrm{H}_{2}\end{array}$ & $\mathrm{R}-4$ & $3 \mathrm{Fe}_{2} \mathrm{O}_{3}(\mathrm{~s})+\mathrm{H}_{2}(\mathrm{~g}) \rightarrow 2 \mathrm{Fe}_{3} \mathrm{O}_{4}(\mathrm{~s})+\mathrm{H}_{2} \mathrm{O}(\mathrm{g})$ & $\mathrm{R}_{4}$ \\
\cline { 2 - 5 } & $\mathrm{R}-5$ & $\mathrm{Fe}_{3} \mathrm{O}_{4}(\mathrm{~s})+\mathrm{H}_{2}(\mathrm{~g}) \rightarrow 3 \mathrm{FeO}(\mathrm{s})+\mathrm{H}_{2} \mathrm{O}(\mathrm{g})$ & $\mathrm{R}_{5}$ \\
\hline $\begin{array}{l}\text { Boudouard } \\
\text { Reaction }\end{array}$ & $\mathrm{R}-7$ & $\mathrm{FeO}(\mathrm{s})+\mathrm{H}_{2}(\mathrm{~g}) \rightarrow \mathrm{Fe}(\mathrm{s})+\mathrm{H}_{2} \mathrm{O}(\mathrm{g})$ & $\mathrm{R}_{6}$ \\
\hline $\begin{array}{l}\text { Water Gas } \\
\text { Reaction }\end{array}$ & $\mathrm{R}-8$ & $\mathrm{C}(\mathrm{s})+\mathrm{H}_{2} \mathrm{O}(\mathrm{g}) \rightarrow \mathrm{CO}+\mathrm{H}_{2}(\mathrm{~g})$ & $\mathrm{R}_{7}[14,21]$ \\
\hline $\begin{array}{l}\text { Flux } \\
\text { Decomposition }\end{array}$ & $\mathrm{R}-9$ & $\begin{array}{l}\mathrm{MeCO}) \\
\mathrm{Mg}(\mathrm{s}) \rightarrow \mathrm{MeO}(\mathrm{s})+\mathrm{CO}(\mathrm{g}), \mathrm{Me}=\mathrm{Ca},\end{array}$ & $\mathrm{R}_{9}[14,21]$ \\
\hline $\begin{array}{l}\text { Water Gas Shift } \\
\text { Reaction }\end{array}$ & $\mathrm{R}-10$ & $\mathrm{H} 2(\mathrm{~g})+\mathrm{CO}(\mathrm{g}) \rightarrow \mathrm{H}_{2} \mathrm{O}(\mathrm{g})+\mathrm{CO}(\mathrm{g})$ & $\mathrm{R}_{10}[14,21]$ \\
\hline $\begin{array}{l}\text { Direct Reduction } \\
\text { of Liquid FeO }\end{array}$ & $\mathrm{R}-11$ & $\mathrm{C}(\mathrm{s})+\mathrm{FeO}(\mathrm{l}) \rightarrow \mathrm{Fe}(\mathrm{l})+\mathrm{CO}(\mathrm{g})$ & $\mathrm{R}_{11}[14,21]$ \\
\hline
\end{tabular}

\subsection{One Interface Unreacted Shrinking Core Model}

As shown in Figure 1, the URC model $[1,2,15]$ assumes that the reduction of an iron oxide sphere occurs at the surface with the formation of an outer shell of metallic iron. The shell grows into the core in the radial direction until the entire oxide is completely reduced to iron. 


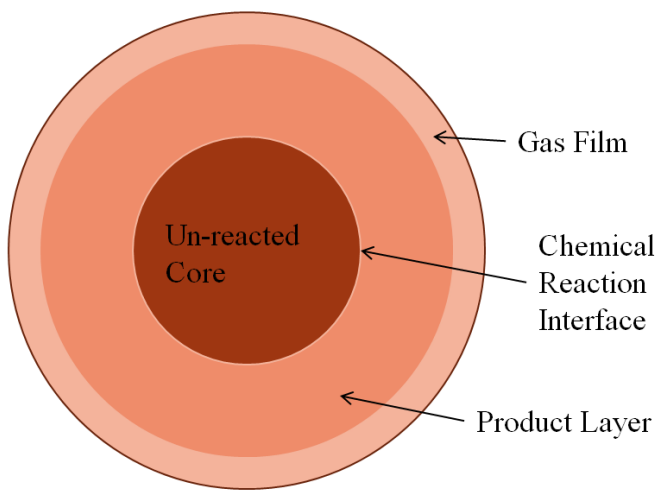

Figure 1. Schematic representation of one Interface unreacted shrinking core model.

The complex process of iron ore reduction is simplified to three rate control processes, namely, gas film resistance, diffusion resistance through the product layer (reduced oxide shell), and chemical reaction resistance at the metal-oxide interface. The expression for the reaction rate for a single pellet is expressed as

$R i=4 \pi r 02 C R-C P K e, i \cdot K e, i(1+K e, i) F+B i+A i$

$C R$ is the reactant species, i.e., $\mathrm{CO}, \mathrm{H}_{2}$. $C P$ is the product species, i.e., $\mathrm{CO}_{2}, \mathrm{H}_{2} \mathrm{O}$. Where the gas film resistance $F$, diffusion resistance $B i$ and chemical reaction resistance $A i$ are expressed as

$F=1 \beta A$

$B i=r O D e \cdot 1-f i-13-1$

$A i=1 k i \cdot 1-f i-23 \cdot K e, i 1+K e, i$.

The fraction of reduction is defined as 
MODELING OF IRON ORE REACTIONS IN BLAST FURNACE SHAFT

fi $=$ weight of oxygen removed from iron oxideweight of removable

oxygen .

$r O$ is the radius of the iron ore. The effective diffusivity is $D e=D o \varepsilon i \tau$. The porosity for different layers are $\varepsilon H M=0.008+0.992 \varepsilon o, \varepsilon M W=0.122+0.878 \varepsilon o$ and $\varepsilon W F=0.435+0.565 \varepsilon o$

[16]. $\varepsilon o$ is the original ore porosity before reaction which is set as 0.25 . $\varepsilon H M$ is the porosity of $\mathrm{Fe}_{3} \mathrm{O}_{4}$ which is the product layer for reaction $\mathrm{R} 1$ and $\mathrm{R} 4 . \varepsilon M W$ is the porosity of $\mathrm{FeO}$ which is the product layer for reaction $\mathrm{R} 2$ and $\mathrm{R} 5 . \varepsilon M W$ is the porosity of Fe which is the product layer for reaction R3 and R6. $\tau$ is the tortuosity which is estimated as 2.0 [17]. $K e, i$ are the equilibrium constants. The kinetic constant of each individual reduction step is $k i=k i, \exp (-E i R T S)$. The values of the frequency factors and activation energies for the six reductions are adopted from the literature [16]. The final rate $R i$ is used as the source term for the governing equations in blast furnace numerical model. 


\subsection{Grain Model}

The grain model assumes that the reaction takes place within a zone rather than being constrained in the interface. Gas diffusion into the ore is included and the distribution of the gas species concentration and ore composition concentration along the radius needs to be modeled.

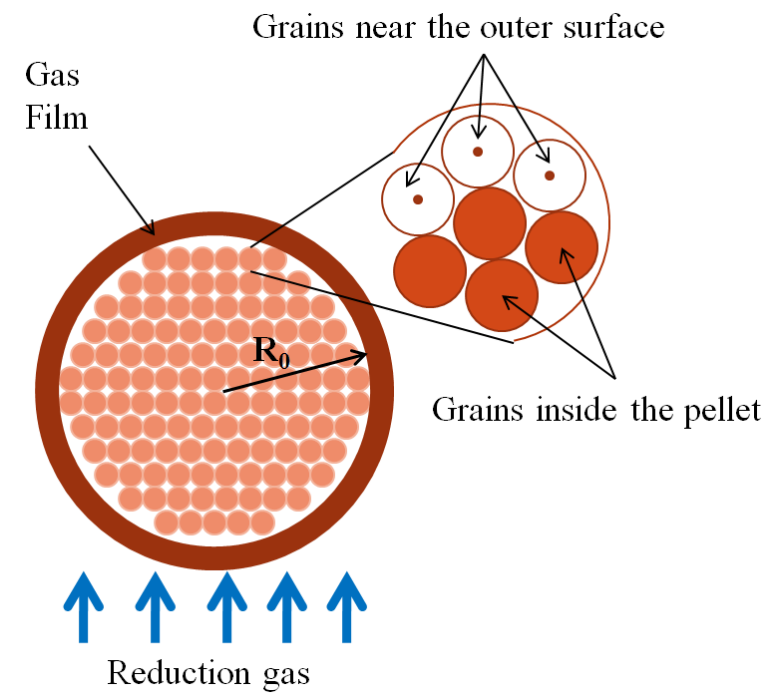

Figure 2. Schematic representation of grain model.

Governing equations for the grain model are summarized from literature [3, 4] as

$1 r 2 d d r r 2 \operatorname{DedCR} d r-v 0=0$

$1 r 2 d d r 2 \operatorname{Ded} C P d r+v 0=0$ 
The reaction rate is obtained when the URC model is applied to each grain inside the pellet [4]. The radius of the grain is $r g=2 \mathrm{~mm}$. Due to the size of the grain is small, only the kinetic resistance is considered as given in

$v 0=31-\varepsilon \operatorname{orgkicR}-c P K e, i(1-f i) 23$.

The kinetic constant of each individual reduction step is $k i=k i$,oexp $(-E i R T s)$. The values of the frequency factors and activation energies for the six reductions are used the same value in URC model [16]. The effective diffusivity $D e=$ Doci $\tau$ is the same expression as the URC model. Do is the molecular diffusion coefficient of $\mathrm{CO}, \mathrm{CO}_{2}, \mathrm{H}_{2}, \mathrm{H}_{2} \mathrm{O}$ depending on the reactant. Molecular diffusivity of a certain species in the gaseous mixture can be calculated [18] by knowing the molecular binary diffusivity from Fuller-Schettler-Giddings equation [19]. For typical blast furnace condition, the molecular diffusivity is calculated as the following. For $\mathrm{CO}, \mathrm{D} o=1.54 \times$ $\mathrm{cm}^{2} / \mathrm{s}$. For $\mathrm{CO}_{2}, D_{o}=1.24 \times \mathrm{cm}^{2} / \mathrm{s}$. For $\mathrm{H}_{2}, D_{o}=0.57 \times \mathrm{cm}^{2} / \mathrm{s}$. For $\mathrm{H}_{2} \mathrm{O}, D o=1.01 \times \mathrm{cm}^{2} / \mathrm{s} . \quad f i$ is the same definition as URC model but it varies locally with the ore radius during the reduction process. $\varepsilon o$ and $\tau$ are set as the same value as URC model. 


\subsection{Implementation of Grain Model}

To incorporate the grain model into the blast furnace CFD model, the iron ore needs to be discretized along the radius direction in 1-D spherical coordinates. In the meantime, the movement of the iron ore within the moving bed is described by 2-D cylindrical coordinates or 3-D Cartesian coordinates. In case of the grain model, the reduction process for a porous ore consists of a number of small grains in blast furnace which is schematically shown in Figure 3. The necessary assumptions for derivation of the governing equations are the followings:

- The ore is spherical with constant radius $\mathrm{R}_{0}$ and it is spherical symmetry.

- The ore is made of spherical grains with constant radius $r g$.

- No crack forms during the reaction.

- Total pressure of gas mixture is uniform in the radial direction of the ore.

- Due to the small Biot number for ore in blast furnace process $(\mathrm{Bi}<0.15$ for ore diameter $15 \mathrm{~mm}$ ), the temperature of the ore is uniform between the ore center and ore surface. 


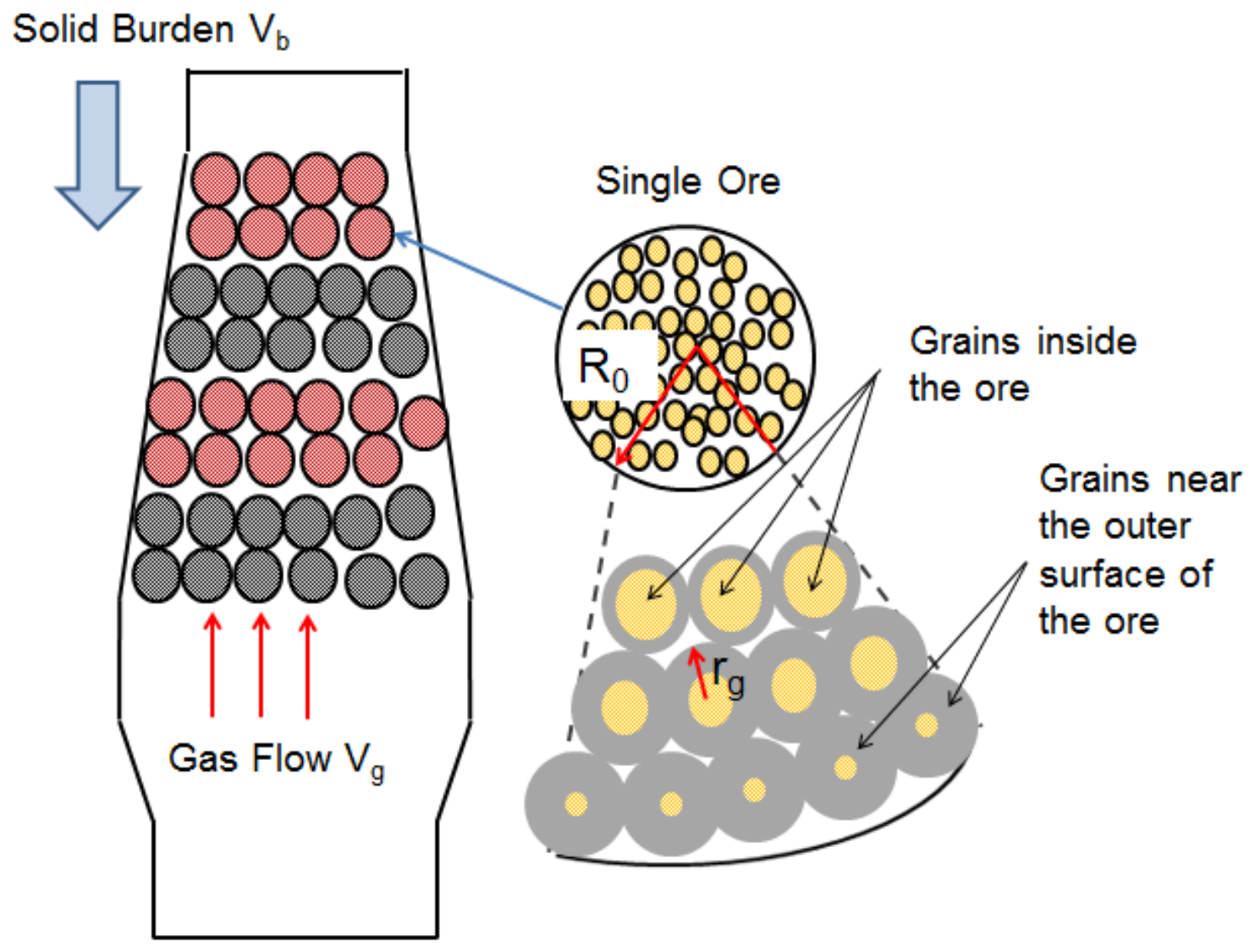

Figure 3. Schematic representation of the reduction process of a porous ore in blast furnace.

The discretization scheme for the implementation of the grain model in the blast furnace numerical model is shown in Figure 4. In the blast furnace numerical model [11], 2-D cylindrical coordinate system is employed for solving general transport equations such as gas flow, temperature, species concentration, etc. Since the grain model requires discretization along the radius of the ore, each ore particle is divided into finite number of shells, similar to the structure of the onion. The values for chemical reaction rate, ore composition concentration, gas 
composition in each shell with the same radius is uniform thus each shell can be taken as one shell group. The shell thickness is one cell distance in the domain of 1-D spherical coordinates. The transport equations for the ore composition concentration, i.e., $\mathrm{Fe}_{2} \mathrm{O}_{3}, \mathrm{Fe}_{3} \mathrm{O}_{4}, \mathrm{FeO}, \mathrm{Fe}$, are solved in each shell group. The transport equations for bulk gas species concentration, i,e, CO, $\mathrm{CO}_{2}, \mathrm{H}_{2}$ and $\mathrm{H}_{2} \mathrm{O}$ are solved in the 2-D cylindrical coordinate system and the values are used as boundary conditions for Eq.(6) and Eq. (7). By this approach, the ore reduction rate is readily available at each shell location. As illustrated in Figure 4, the ore is divided into three shells. The conservation equation is solved in the 2-D cylindrical coordinates for each shell group $\mathrm{n}$. The indexes for the cell in 2-D cylindrical coordinate system are $i$ and $j$ ( $i$ is omitted in Figure 4 because only the vertical direction is illustrated). Iteration is simultaneously conducted in both the 2-D cylindrical coordinates and 1-D spherical coordinates until a converged solution is obtained. The detailed discretization for the grain model in 1D spherical coordinates is published previously [14]. The flowchart of the iterative scheme is shown in Figure 5. 


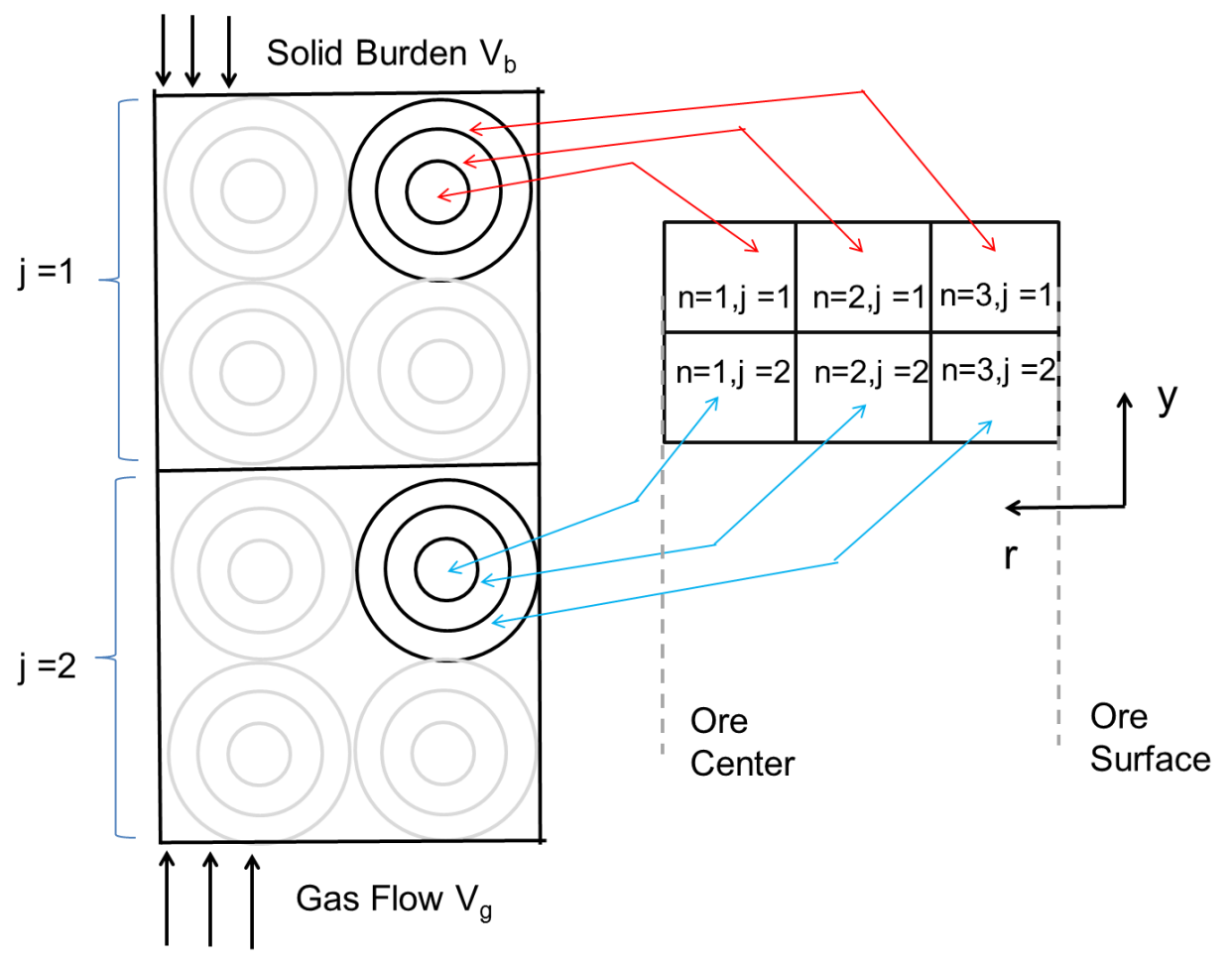

Figure 4. Schematic representation of the discretization of the porous ore in the moving bed configuration in the blast furnace.

Burden composition conservation equations for shell group $\mathrm{n}$ in 2-D cylindrical coordinate system are given as

$\nabla \cdot u b n o C F e 2 O 3, n=S b, F e 2 O 3, n$

$\nabla \cdot u$ bnoCFe $304, n=S b, F e 3 O 4, n$

$\nabla \cdot u b n o C F e O, n=S b, F e O, n$ 
$\nabla \cdot u b n o C F e, n=S b, F e, n$.

$\boldsymbol{u} \boldsymbol{b}$ is the burden descending velocity which is solved in the 2-D cylindrical coordinates system. no is the number density of the iron ore. The governing equations for $\boldsymbol{u b}$ and the bulk gas species concentrations (gas species concentration outside the ore) can be found in pervious publication [11] Gas concentration conservation equations for each CFD cell $\mathrm{j}$. Here $\mathrm{j}$ is corresponding to the two 2-D cylindrical cells in vertical direction as illustrated in Figure 4. The gas species inside the pellets in each 1D cell is expressed as

$1 r 2 d d r r 2 D e, n d C R, n d r-v 0, \mathrm{n}=0$

$1 r 2 d d r r 2 D e, n d C P, n d r+v 0, \mathrm{n}=0$

The boundary conditions for the Eq. (13) and Eq. (14) are for the continuity mass flux on the surface of the ore $r=R O a \mathrm{as}$

$D e, n=s d C n=s d r=k R(C b-C n=s)$

$k R$ is the mass transfer coefficient expressed as $k R=(0.2+0.6 \operatorname{Re} 0.5 \mathrm{Sc} 0.333) \mathrm{Do} 2 r \mathrm{O}, \mathrm{Cb}$ is the bulk gas species concentrations which are solved in the 2-D cylindrical coordinate system. $C n=s$ is the gas species concentration at the surface of the ore. Due to spherical symmetry, at the center of the ore $r=0$, the boundary condition is given as: 
MODELING OF IRON ORE REACTIONS IN BLAST FURNACE SHAFT

$d C n=c d r=0$ 


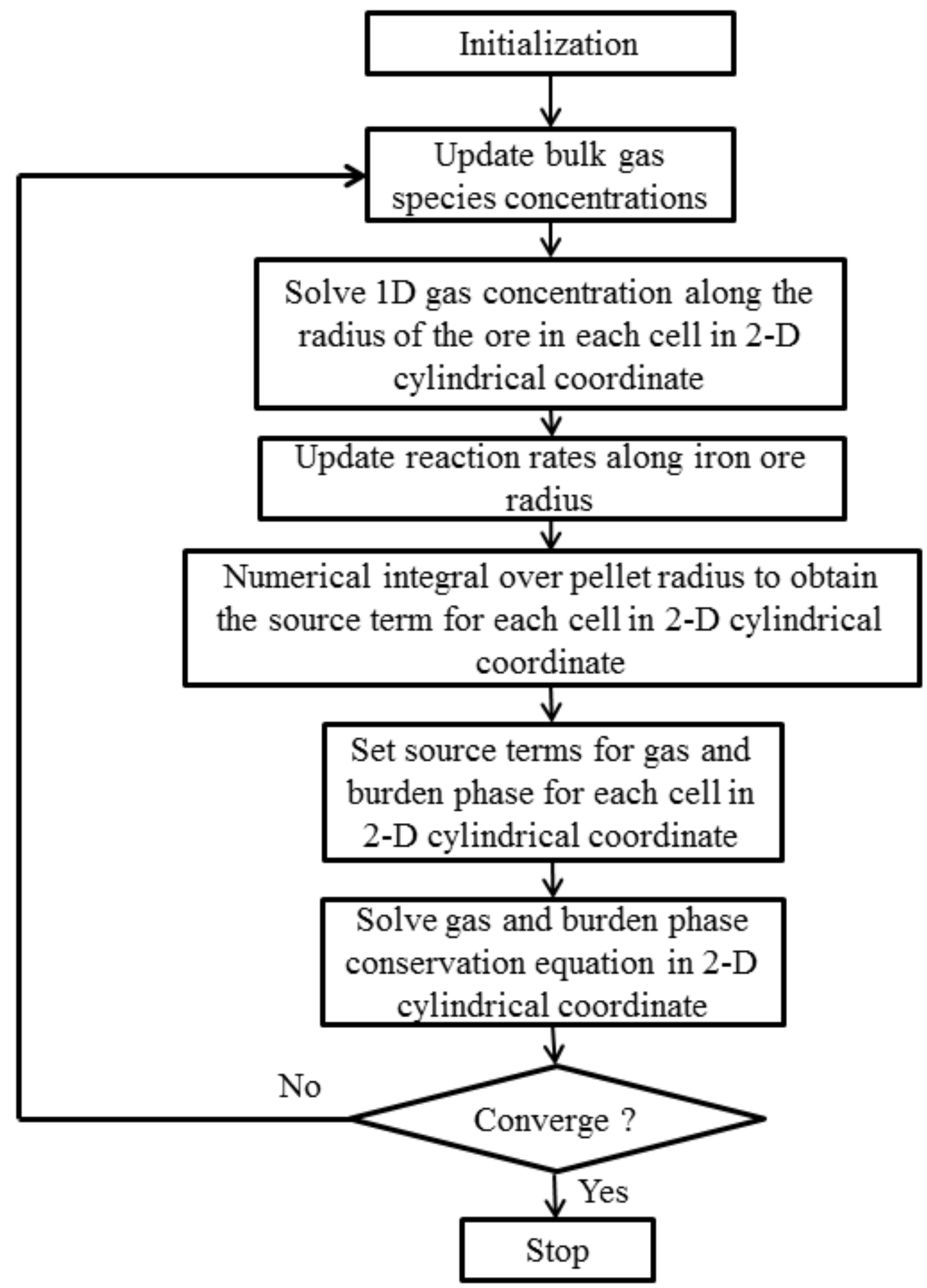

Figure 5. Flowchart of the iterative scheme 


\section{Results and Discussion}

\subsection{Grain Model Results}

The simulation conditions for industry blast furnace are reported previously [11]. The nonuniform burden descending velocity along the furnace radius is also considered [20]. It is assumed the burden descending velocity is linearly distributed from the furnace center to the furnace wall. The burden descending velocity in the center is 0.8 of the velocity near the furnace wall. The predicted gas streamline, gas temperature and bulk gas species concentrations are shown in Figure 6 (a)-(f). The gas streamline in Figure 6 (a) illustrations the zigzag flow pattern caused by the difference in porosity of the coke and ore layer. The ore layered inside $\mathrm{CZ}$ possesses a much lower porosity due to the fusion of the iron ore burden. The ore layer inside $\mathrm{CZ}$ has a porosity of 0.1 and it is observed that the $\mathrm{CZ}$ the ore layers become virtually impermeable thus forcing the ascending gas to pass through the coke slits present between the ore layers. The ore temperature and the reduction process from $\mathrm{Fe}_{2} \mathrm{O}_{3}$ to $\mathrm{Fe}$ are shown in Figure $6(\mathrm{~g})-(\mathrm{k})$. 


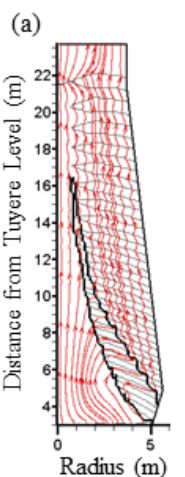

(g)

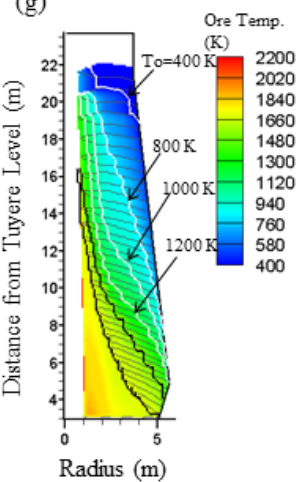

(b)

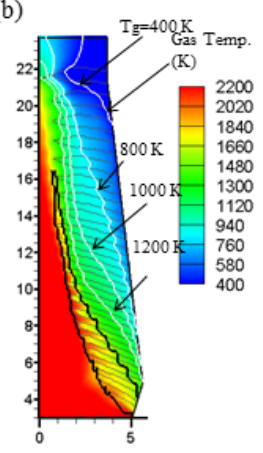

(h)

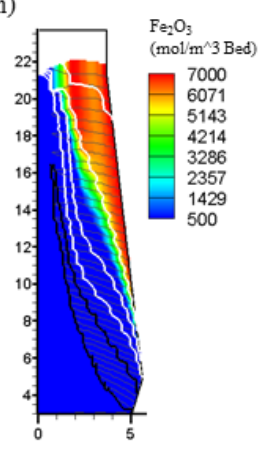

(c)

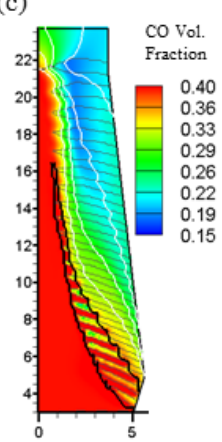

(d)
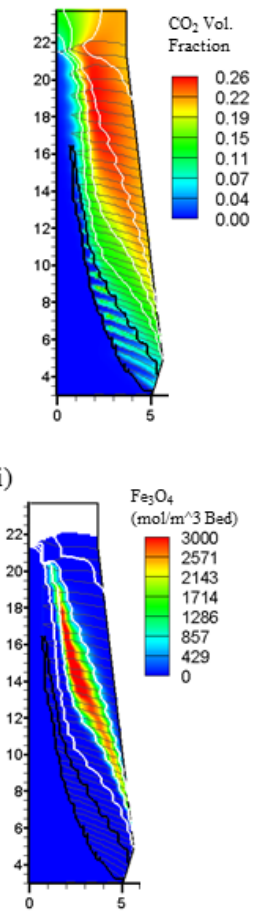

(e)

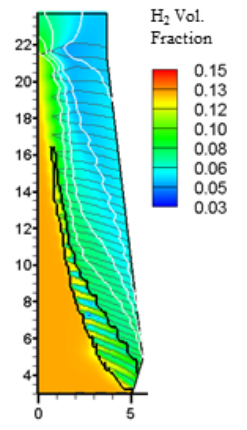

(j)

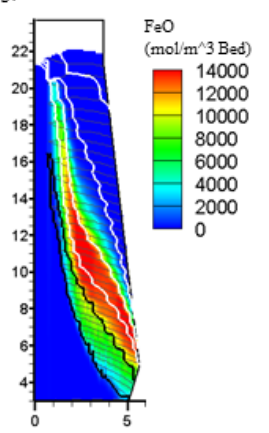

(f)

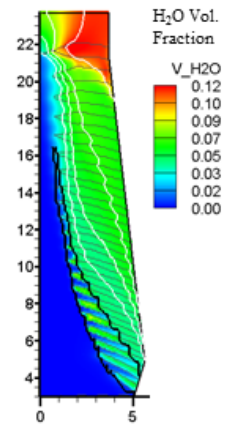

(k)

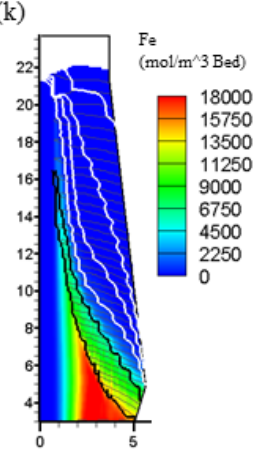

Figure 6. Reduction process in shaft: (a) gas streamline, (b) gas temperature, (c) CO, (d) $\mathrm{CO}_{2}$, (e) $\mathrm{H}_{2}$, (f) $\mathrm{H}_{2} \mathrm{O}$, (g) ore temperature, (h) $\mathrm{Fe}_{2} \mathrm{O}_{3}$, (i) $\mathrm{Fe}_{3} \mathrm{O}_{4}$, (j) $\mathrm{FeO}$, (k) Fe

Figure 7 (a) shows the reduction degree which has a minimum value of zero and maximum value of unity. Figure 7 (b) shows the reduction process of the ore from $\mathrm{Fe}_{2} \mathrm{O}_{3}$ to $\mathrm{Fe}$ along a vertical line at the furnace radius 3.3m location as indicated in Figure 7 (a). 


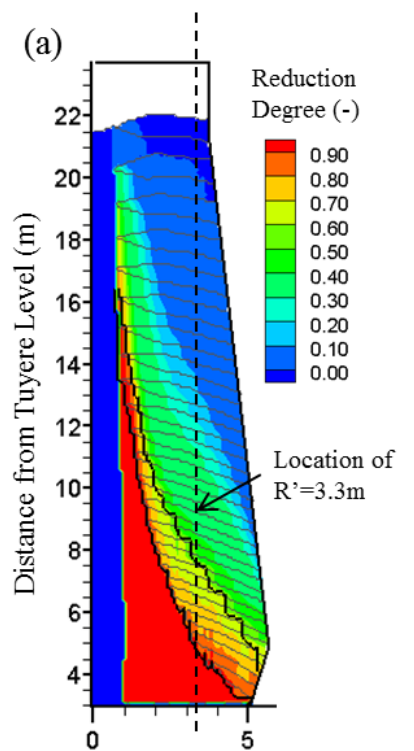

Furnace Radius (m) (b)

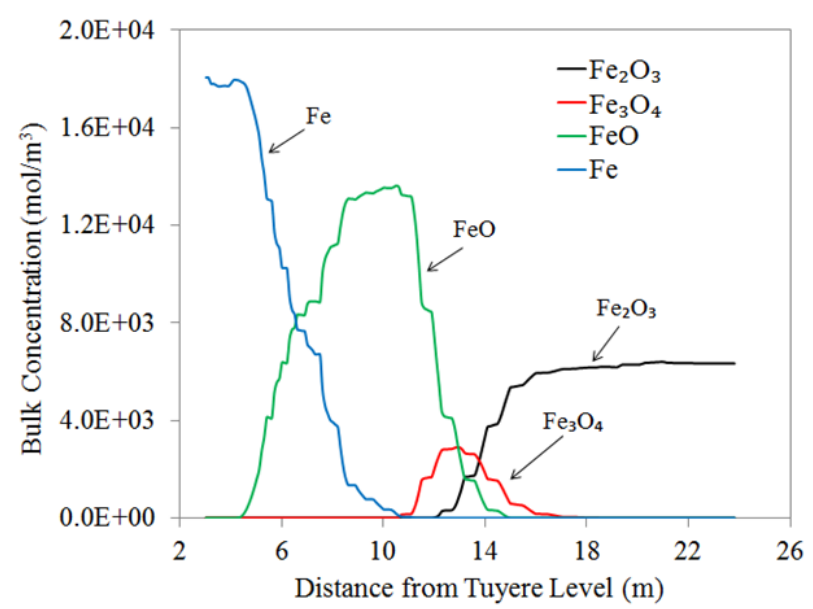

Figure 7. Reduction process in shaft: (a) distribution of the reduction degree, (b) Ore concentration along a vertical line.

The ore is discretized along the radial direction. The distribution of $\mathrm{Fe}_{3} \mathrm{O}_{4}$ at different radius of the ore is given in Figure 8 (a). The concentration is expressed as per unit ore volume, i.e., amount divided by one ore volume. The region near the ore surface exhibits a lower $\mathrm{Fe}_{3} \mathrm{O}_{4}$ concentration due to fast reduction of $\mathrm{Fe}_{3} \mathrm{O}_{4}$ to $\mathrm{FeO}$ near the surface. Five locations namely " $\mathrm{A}$ " to "E" along the pervious vertical line were selected to examine the distribution along the ore radius. Figure 8 (b) shows the radial distribution of $\mathrm{Fe}_{3} \mathrm{O}_{4}$ at those five locations. The descending velocity vector of the ore burden is very close to a straight vertical line so A to E approximately represents the reduction history of an ore pellet in the moving bed. From A, B and C, it can be seen from that the reduction from $\mathrm{Fe}_{2} \mathrm{O}_{3}$ to $\mathrm{Fe}_{3} \mathrm{O}_{4}$ takes place uniformly in the entire ore. From $\mathrm{C}$, $\mathrm{D}$ and $\mathrm{E}$, the reduction from $\mathrm{Fe}_{3} \mathrm{O}_{4}$ to $\mathrm{FeO}$ begins outside of the ore and gradually spreads into the core of the ore. 

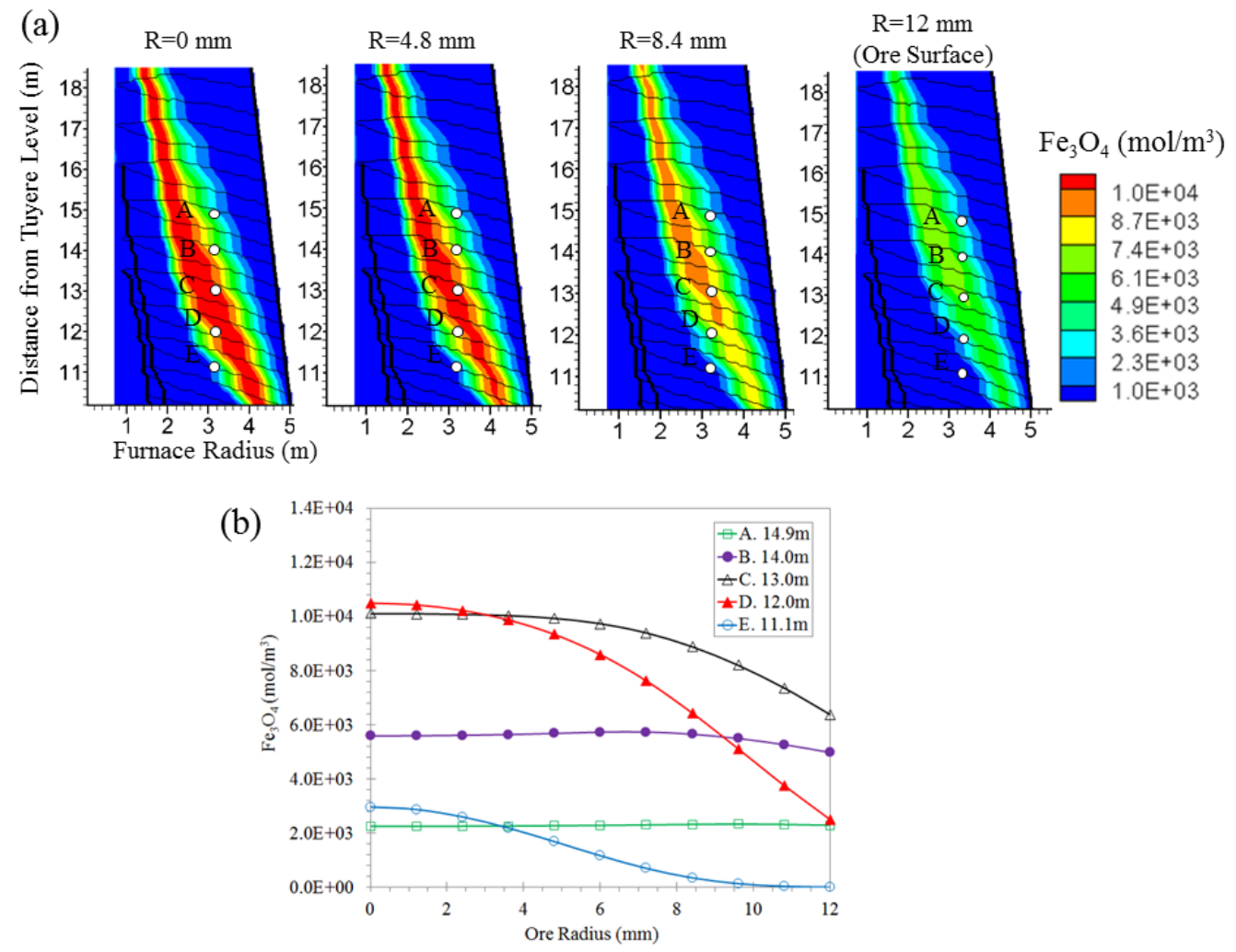

Figure 8. Distribution of $\mathrm{Fe}_{3} \mathrm{O}_{4}$ at middle shaft: (a) contour at different ore radius (b) radial distribution inside ore at different furnace locations.

The reduction potential of the $\mathrm{CO}$ in the bulk gas is shown in Figure 9 (a). The potential decreases inside the ore due to the consumption of the $\mathrm{CO}$ and generation of $\mathrm{CO}_{2}$. Similarly, the reduction potential of $\mathrm{H}_{2}$ is given in Figure 10 (a) and (b). 
(a)

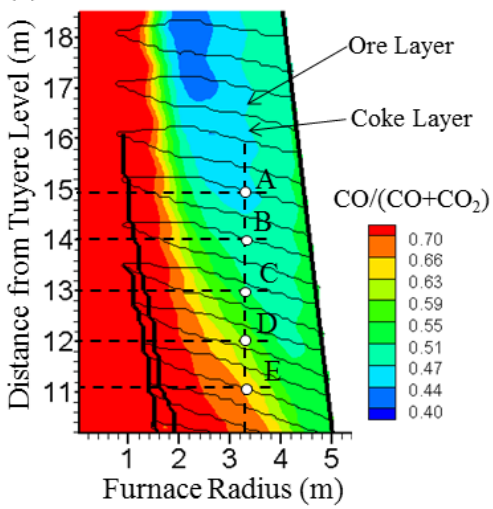

(b)

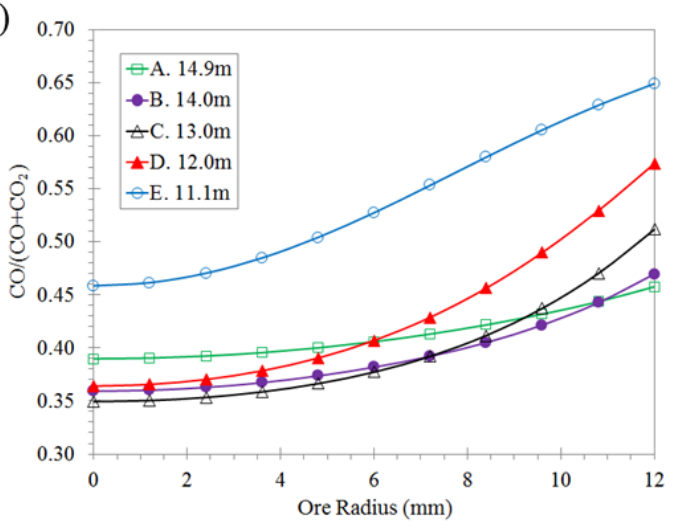

Figure 9. Distribution of $\mathrm{CO} /\left(\mathrm{CO}+\mathrm{CO}_{2}\right)$ at middle shaft: (a) bulk gas (b) radial distribution inside ore at different furnace locations.

(a)

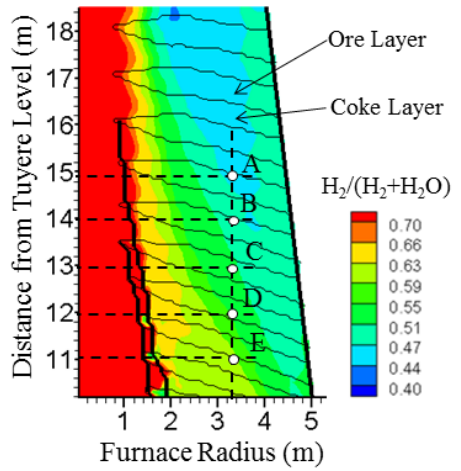

(b)

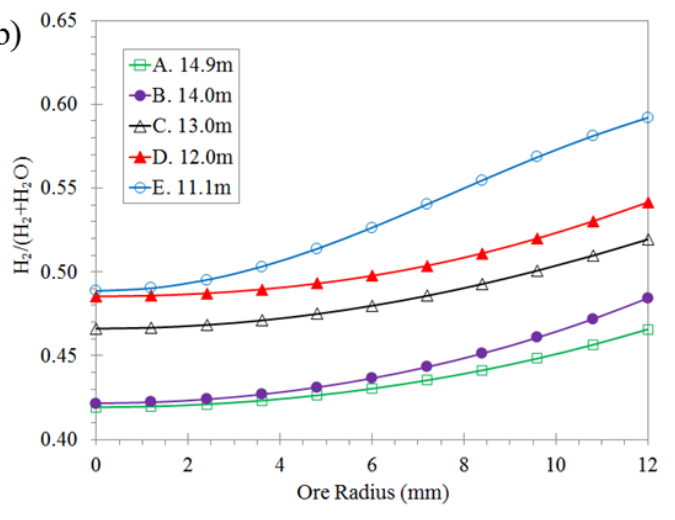

Figure 10. Distribution of $\mathrm{H}_{2} /\left(\mathrm{H}_{2}+\mathrm{H}_{2} \mathrm{O}\right)$ at middle shaft: (a) bulk gas (b) radial distribution inside ore at different furnace locations.

The calculated ore temperatures in those five locations are given in Table 2. Comparing the equilibrium gas composition with the gas distribution inside the ore, it can be found the reduction of $\mathrm{Fe}_{3} \mathrm{O}_{4}$ to $\mathrm{FeO}$ is limited by the reaction equilibrium at location $\mathrm{A}, \mathrm{B}$, and $\mathrm{C}$ because of the low ore temperature. Therefore, it is import to keep a high temperature burden at the middle shaft to ensure the fast reduction of $\mathrm{Fe}_{3} \mathrm{O}_{4}$ to $\mathrm{FeO}$. 
Table 2. Equilibrium gas composition for $\mathrm{Fe}_{3} \mathrm{O}_{4}$ reduction.

\begin{tabular}{|c|c|c|c|c|}
\hline Location & $\begin{array}{c}\text { Distance } \\
\text { from Tuyere } \\
\text { Level }\end{array}$ & $\begin{array}{c}\text { Ore } \\
\text { Temp. } \\
(\mathrm{K})\end{array}$ & $\begin{array}{c}\text { Equilibrium } \\
\mathrm{CO} /\left(\mathrm{CO}+\mathrm{CO}_{2}\right) \\
\mathrm{R}-2\end{array}$ & $\begin{array}{c}\text { Equilibrium } \\
\mathrm{H}_{2} /\left(\mathrm{H}_{2}+\mathrm{H}_{2} \mathrm{O}\right) \text { of } \mathrm{R}-5\end{array}$ \\
\hline A & $14.9 \mathrm{~m}$ & 832 & 0.43 & 0.74 \\
\hline B & $14.0 \mathrm{~m}$ & 871 & 0.38 & 0.65 \\
\hline C & $13.0 \mathrm{~m}$ & 911 & 0.34 & 0.56 \\
\hline D & $12.0 \mathrm{~m}$ & 952 & 0.30 & 0.47 \\
\hline E & $11.1 \mathrm{~m}$ & 1030 & 0.24 & 0.31 \\
\hline
\end{tabular}

The reduction in the lower shaft region is mainly involving the transforming of FeO to Fe. Figure 11 (a) shows the concentration of Fe at different radius of the ore in the lower region of shaft. The surface of the ore is reduced to $\mathrm{FeO}$ above the $\mathrm{CZ}$, while the $\mathrm{FeO}$ in the center of the ore survives even below the lower boundary of the CZ. Figure 11 (b) shows the radial distribution of $\mathrm{FeO}$ at different locations. Contrasting with the reduction of $\mathrm{Fe}_{2} \mathrm{O}_{3}$ or $\mathrm{Fe}_{3} \mathrm{O}_{4}$, a sharp reduction interface is observed for $\mathrm{FeO}$ reduction. The grain model reveals that the reduction process of $\mathrm{FeO}$ is consisted with the assumption of the URC model. 

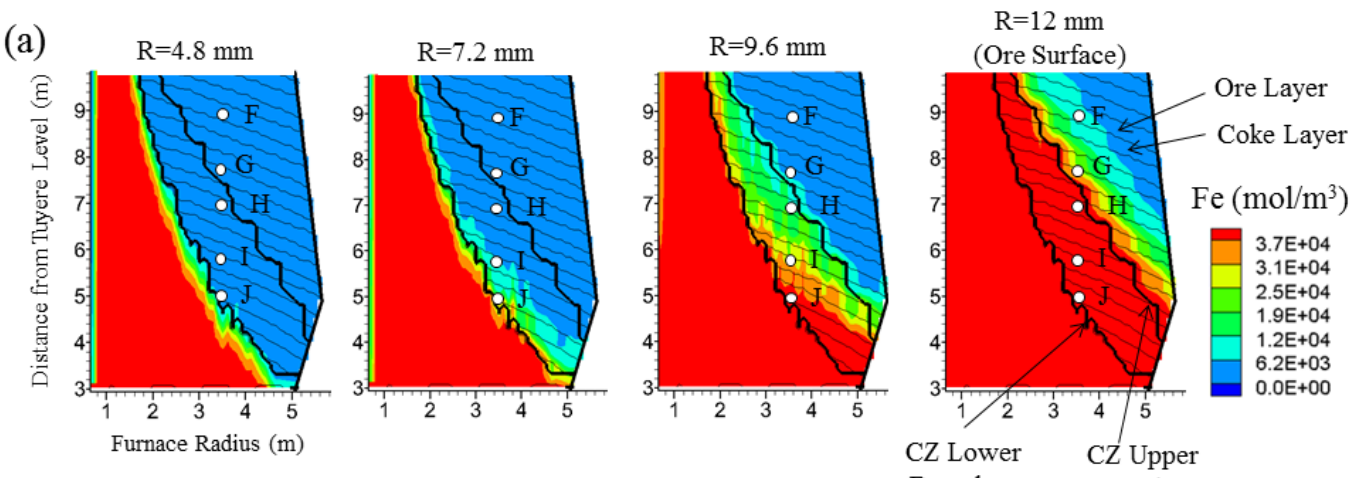

(b)

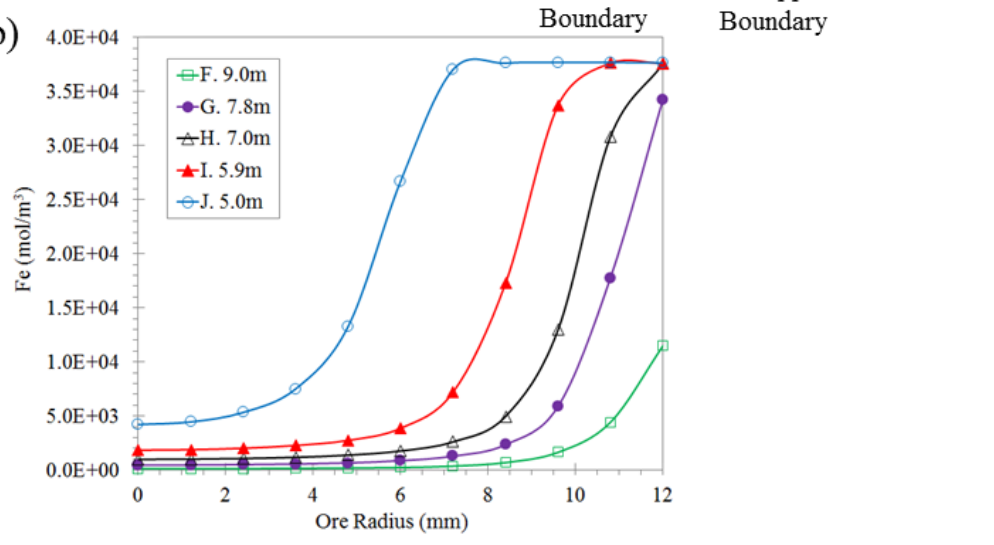

Figure 11. Distribution of Fe at lower shaft: (a) contour at different ore radius (b) radial distribution inside ore at different furnace locations.

The reduction potential of $\mathrm{CO}$ is shown in Figure 12 (a). The bulk potential drops significantly over the $\mathrm{CZ}$ indicating most of the $\mathrm{FeO}$ reduction takes place in the vicinity of the $\mathrm{CZ}$. Figure 12 (b) shows that most of the $\mathrm{FeO}$ is reduced inside the $\mathrm{CZ}$ because of the relatively high equilibrium $\mathrm{CO} /\left(\mathrm{CO}+\mathrm{CO}_{2}\right)$ as listed in Table 3. The potential of $\mathrm{H}_{2}$ is shown in Figure 13 (a) and (b). It is found that the gas distribution in location $\mathrm{J}$ shows that $\mathrm{H}_{2}$ penetrates deeper into the ore center than $\mathrm{CO}$ for $\mathrm{FeO}$ reduction. Therefore, it is beneficial to increase the $\mathrm{H}_{2}$ content in the bosh gas to reduce the amount of direct reduction of FeO. 

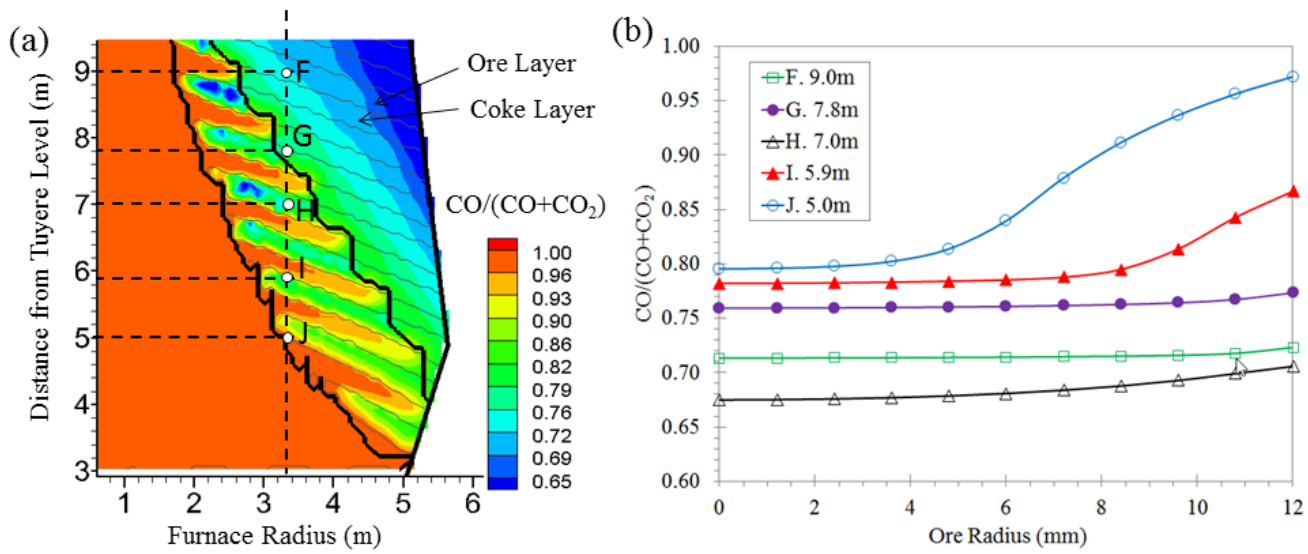

Figure 12. Distribution of $\mathrm{CO} /\left(\mathrm{CO}+\mathrm{CO}_{2}\right)$ at lower shaft: (a) bulk gas (b) radial distribution inside ore at different furnace locations.
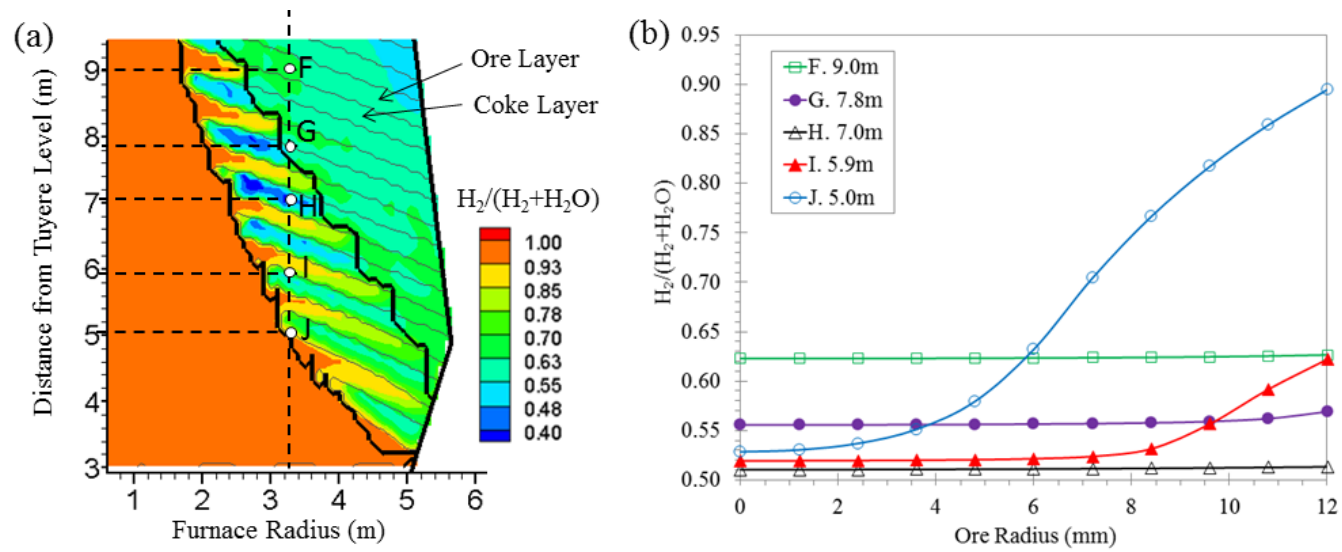

Figure 13. Distribution of $\mathrm{H}_{2} /\left(\mathrm{H}_{2}+\mathrm{H}_{2} \mathrm{O}\right)$ at lower shaft: (a) bulk gas (b) radial distribution inside ore at different furnace locations. 
Table 3 Equilibrium gas composition for $\mathrm{FeO}$ reduction.

\begin{tabular}{|c|c|c|c|c|}
\hline Location & $\begin{array}{c}\text { Distance } \\
\text { from } \\
\text { Tuyere } \\
\text { Level }\end{array}$ & $\begin{array}{c}\text { Ore Temp. } \\
(\mathrm{K})\end{array}$ & $\begin{array}{c}\text { Equilibrium } \\
\mathrm{CO} /\left(\mathrm{CO}+\mathrm{CO}_{2}\right. \\
\text { ) of } \mathrm{R}-3\end{array}$ & $\begin{array}{c}\text { Equilibrium } \\
\mathrm{H}_{2} /\left(\mathrm{H}_{2}+\mathrm{H}_{2} \mathrm{O}\right) \\
\text { of R-6 }\end{array}$ \\
\hline $\mathrm{F}$ & $9.0 \mathrm{~m}$ & 1260 & 0.72 & 0.62 \\
\hline $\mathrm{G}$ & $7.8 \mathrm{~m}$ & 1470 & 0.76 & 0.56 \\
\hline $\mathrm{H}$ & $7.0 \mathrm{~m}$ & 1590 & 0.78 & 0.53 \\
\hline $\mathrm{I}$ & $5.9 \mathrm{~m}$ & 1650 & 0.79 & 0.52 \\
\hline $\mathrm{J}$ & $5.0 \mathrm{~m}$ & 1680 & 0.79 & 0.52 \\
\hline
\end{tabular}

\subsection{Comparison of the Grain Model and the URC model}

The grain model provides much more detailed information on the reduction process than the URC model. Despite the reduction of $\mathrm{Fe}_{2} \mathrm{O}_{3}$ and $\mathrm{Fe}_{3} \mathrm{O}_{4}$ does not follow the assumption of URC model, a sharp reduction interface is observed for $\mathrm{FeO}$ reduction. The grain model reveals that the reduction process of $\mathrm{FeO}$ is consisted with the assumption of the URC model. The coke rate and gas utilization in blast furnace shaft is mainly depended on the reductions of $\mathrm{FeO}$ and coke reactions. Although the reduction process is different in the upper part of the furnace, such difference will not have a significant effect on the reactions in the lower part of the furnace. Figure 14 shows the reduction process along the vertical line given in Figure 7 (a). Slight 
difference exists in the upper part of the furnace where the reduction of $\mathrm{Fe}_{2} \mathrm{O}_{3}$ and $\mathrm{Fe}_{3} \mathrm{O}_{4}$ does not follow the sharp reduction interface assumption.

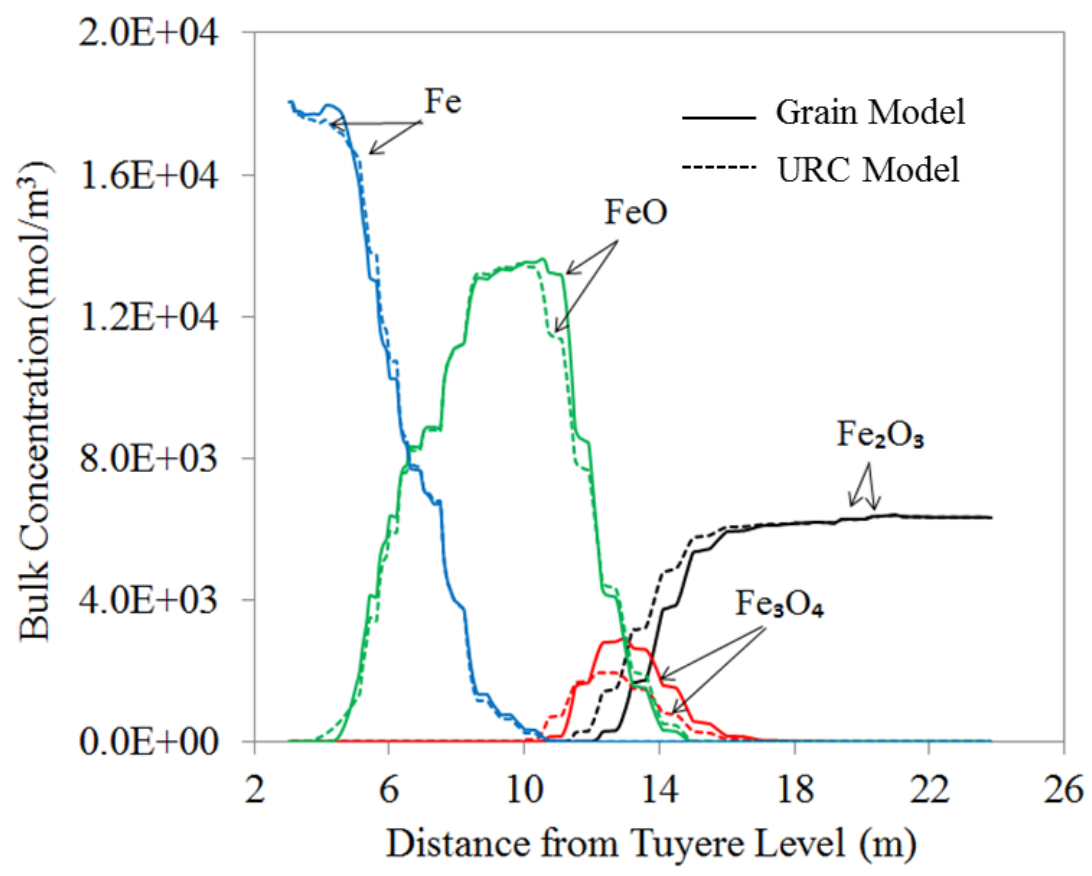

Figure 14. Comparison of the grain model and URC model.

The average top gas composition is usually available for commercial blast furnace. Some furnaces are also equipped with above burden probe that measures the gas temperature and composition changing along the radius of the furnace at furnace top. The moveable in-burden probe is horizontally inserted into the burden to sample the gas for temperature and composition measurement. The measurement data from four furnaces namely A, B, C and D are used for the validation of the CFD model. The predicted value is comparable with the average value of measurement data from three above burden probe at different locations. 
The mixed top gas is further analysis for determined the averaged composition and temperature. The comparison of the averaged top gas composition and temperature for another furnace are given in Table 4. As can be seen from the table, the average top gas from CFD is approximately $25 \mathrm{~K}$ higher than the measured data. The heat escaped from the furnace wall is only taking the heat loss through cooling stave into consideration and others forms of heat loss such as radiation are neglected. The coke rate and pressure drop agree well with the measured value. 
Table 4 Comparison of the top gas measurement, coke rate and pressure drop.

\begin{tabular}{|c|c|c|c|c|c|}
\hline & $\begin{array}{c}\text { Measured } \\
\text { Value }\end{array}$ & $\begin{array}{c}\text { Grain } \\
\text { Model }\end{array}$ & $\begin{array}{c}\text { Error* of Grain } \\
\text { Model }\end{array}$ & $\begin{array}{c}\text { URC } \\
\text { Model }\end{array}$ & $\begin{array}{c}\text { Error* of URC } \\
\text { Model }\end{array}$ \\
\hline Top Gas CO & 0.236 & 0.243 & $-3.1 \%$ & 0.244 & $-3.6 \%$ \\
\hline Top Gas CO 2 & 0.219 & 0.227 & $-3.6 \%$ & 0.227 & $-3.6 \%$ \\
\hline Top Gas $\mathrm{H}_{2}$ & 0.063 & 0.064 & $-3.0 \%$ & 0.063 & $-1.5 \%$ \\
\hline $\begin{array}{c}\text { Top Gas N } \\
\text { Top Gas } \\
\mathrm{CO}_{2} /\left(\mathrm{CO}+\mathrm{CO}_{2}\right)\end{array}$ & 0.475 & 0.465 & $2.0 \%$ & 0.465 & $1.9 \%$ \\
\hline $\begin{array}{c}\text { Top Gas Temp. } \\
\text { (K) }\end{array}$ & 394 & 418 & $6.0 \%$ & 418 & $0.48 \%$ \\
\hline $\begin{array}{c}\text { Coke Rate } \\
\text { (kg/MTHM) }\end{array}$ & 412 & 414 & $-0.6 \%$ & 415 & $-0.8 \%$ \\
\hline $\begin{array}{c}\text { Pressure Drop } \\
\text { (Pa) }\end{array}$ & $1.627 \times 10^{5}$ & $1.635 \times 10^{5}$ & $-0.5 \%$ & $1.615 \times 10^{5}$ & $0.7 \%$ \\
\hline
\end{tabular}

* Error is defined as (Predicted Value - Measured Value )/ Measured Value $\times 100 \%$

The normalized data of the top gas measurement including the average top gas $\mathrm{CO}, \mathrm{CO}_{2}, \mathrm{H}_{2}, \mathrm{~N}_{2}$ and temperature for four furnaces are shown in Figure 15. Most of the predicated value is within $5 \%$ variation of the measured one. The largest error is about $15 \%$ and the large errors are from the same furnace. It may contribute to the accuracy of the measurement for that specific furnace. Both grain model and URC model are used for calculation. The grain model yield slightly more accurate results than the URC model. The limited improvement is due to that the top gas 
concentration and temperature is mainly depended on the reductions of $\mathrm{FeO}$, whose reduction process follows the assumption of the URC model. However, the grain model provides more detailed description about the reduction process and it can be used to determine the rate controlling factors in order to provide guidelines for improving the blast furnace process.

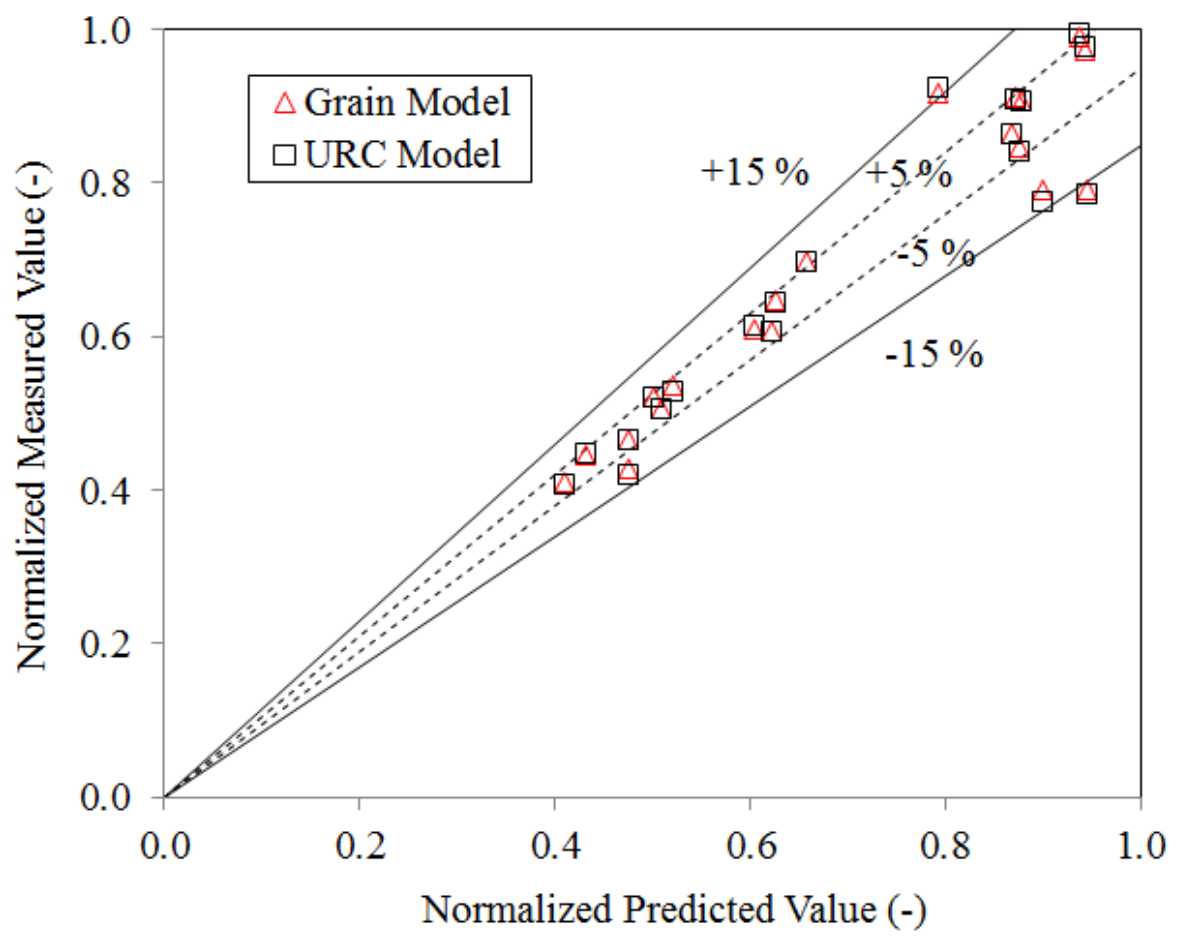

Figure 15. Comparison of the top gas measurement for other furnaces. 


\section{Conclusion}

In this paper, a novel methodology is proposed to implement the grain model to full blast furnace numerical model for predicting iron ore reduction in blast furnace. The model considers the gas diffusion in porous iron ore, the dynamic composition changes of iron ore along the radius of the iron ore, the iron ore transport in blast furnace. The gas flow and heat transfer are also considered. The result reveals the detailed heat and mass transfer process for the iron ore reduction in blast furnace shaft. This novel method not only applies to the iron ore reduction in blast furnace but also suits for the general moving bed reduction system such as shaft furnace. In addition, the URC model and grain model in blast furnace modeling are compared. The grain model yield slightly more accurate results than the URC model. 


\section{Acknowledgement}

This research was supported by the American Iron and Steel Institute (AISI) and the U.S. Department of Energy (DOE) under Award No. DE-FG36-07GO17041. The authors would like

to thank the support from the collaborators at ArcelorMittal-USA, ArcelorMittal-Dofasco, SeverStal, US Steel, US Steel - Stelco Inc., and Union Gas. 


\title{
Nomenclature
}

\author{
$A i \quad$ Chemical reaction resistance \\ $B i \quad$ Diffusion resistance \\ $C A \quad$ Reactant gas concentration, $\mathrm{mol} / \mathrm{m}^{3}$ \\ CCO Concentrate of $\mathrm{CO}$ inside the pellet, $\mathrm{mol} / \mathrm{m}^{3}$ \\ CCO2 Concentrate of $\mathrm{CO}_{2}$ inside the pellet, $\mathrm{mol} / \mathrm{m}^{3}$ \\ $C p \quad$ Heat capacity, $\mathrm{J} /(\mathrm{kg} . \mathrm{K})$ \\ DO Throat diameter, $\mathrm{m}$ \\ $D C O e$ Effective diffusivity of CO inside pellet, $\mathrm{m}^{2} / \mathrm{s}$ \\ DCO2e Effective diffusivity of $\mathrm{CO}_{2}$ inside pellet, $\mathrm{m}^{2} / \mathrm{s}$ \\ $D e, i \quad$ Effective diffusivity of the product layer, $\mathrm{m}^{2} / \mathrm{s}$ \\ $D e^{\prime} \quad$ Effective diffusive coefficient of CO through the surface layer, $\mathrm{cm}^{2} / \mathrm{s}$ \\ $F \quad$ Gas film resistance \\ ki Reaction constant, $\mathrm{cm} / \mathrm{s}$ \\ $K e, i \quad$ Equilibrium constant \\ $L \quad$ Vertical distance of the burden profile, $m$ \\ $r \quad$ Radial direction, $\mathrm{m}$ \\ rO Radius of the iron pellet, $\mathrm{m}$ \\ $r g \quad$ Radius of the grain, $m$ \\ $R \quad$ Gas constant, $\mathrm{J} /(\mathrm{K} . \mathrm{mol})$ \\ $R i \quad$ Reaction rate, $\mathrm{mol} /\left(\mathrm{m}^{3} . \mathrm{s}\right)$
}


SO Specific surface area, $\mathrm{cm}^{2} / \mathrm{cm}^{3}$

$T \quad$ Temperature, $\mathrm{K}$

$\boldsymbol{u} \boldsymbol{b}$ Burden velocity, $\mathrm{m} / \mathrm{s}$

vO Reduction rate of the concentrates, $\mathrm{mol} /\left(\mathrm{cm}^{3} . \mathrm{s}\right)$

XO Local un-reacted degree

$\alpha \quad$ Shape factor of the concentrate

$\beta \quad$ Micro-structure of the fine pellets

$\gamma \quad$ Fracture factor

$\varepsilon \quad$ Porosity

$\tau \quad$ Tortuosity

$\rho \quad$ Density, $\mathrm{m}^{3} / \mathrm{kg}$

$\psi \mathrm{mg}$ Volumetric fraction of the iron concentrate 


\section{References}

1. Strassburger, J.H. (Ed.), 1969, "Blast Furnace Theory and Practice," Gordon and Breach Science Publishers, 2

2. Omori, Y., 1987, "Blast Furnace Phenomena and Modeling”, Elsevier Applied Science, London.

3. Huang, D., Yang, X., Yang, X., Kong L., 1996, "Kinetics and Mathematical Model for Reduction Process of Iron Ore Briquette Containing Carbon," ACTA METALLURGICA SINICA (Chinese edition), 32(6), pp. 629-636.

4. Valipour, M.S., Hashemi, M.M. and Saboohi, Y., 2006. Mathematical modeling of the reaction in an iron ore pellet using a mixture of hydrogen, water vapor, carbon monoxide and carbon dioxide: an isothermal study. Advanced Powder Technology, 17(3), pp.277-295.

5. Spitzer, R. H., Manning, F.S. and Philbrook, W.O., 1966, "Mixed-control Reaction Kinetics in the Gaseous Reduction of Hematite," AIME Met Soc Trans, 236(5), pp.726-742.

6. Spitzer, R. H., Manning, F. S., and Philbrook, W. O., 1966, "Generalized Model for the Gaseous, Topochemical Reduction of Porous Hematite Spheres," AIME Met Soc Trans, 236(12), pp.1715-1724.

7. Yagi, J., Sasaki, K. and Muchi, I., 1968. Theoretical investigations of the blast furnace operations with the aid of mathematical models. Tetsu-to-Hagané, 54, p.1019.

8. Bi, X., Torssell, K. and Wijk, O., 1992. Simulation of the Blast Furnace Process by a Mathematical Model. ISIJ international, 32(4), pp.470-480.

9. Austin, P.R., Nogami, H. and Yagi, J.I., 1997. A Mathematical Model for Blast Furnace Reaction Analysis Based on the Four Fluid Model. ISIJ international, 37(8), pp.748-755.

10. Dong, X.F., Yu, A.B., Chew, S.J. and Zulli, P., 2010. Modeling of blast furnace with layered cohesive zone. Metallurgical and Materials Transactions B, 41(2), pp.330-349.

11. Fu, D., Chen, Y., Zhao, Y., D'Alessio, J., Ferron, K.J. and Zhou, C.Q., 2014. CFD modeling of multiphase reacting flow in blast furnace shaft with layered burden. Applied Thermal Engineering, 66(1), pp.298-308.

12. Shen, Y., Guo, B., Chew, S., Austin, P. and Yu, A., 2015. Three-Dimensional Modeling of Flow and Thermochemical Behavior in a Blast Furnace. Metallurgical and Materials Transactions B, 46(1), pp.432-448.

13. Takatani, K., Inada, T. and Ujisawa, Y., 1999. Three-dimensional dynamic simulator for blast furnace. ISIJ international, 39(1), pp.15-22.

14. Fu, D., 2014. Numerical simulation of ironmaking blast furnace shaft. PhD Thesis, Purdue University 
15. Xie, Y., and Qin, M., 1984, "A Mathematical Model for Reduction of Iron Ore in Moving Bed," Acta Metallurgica Sinica, Series B, 20, pp.249-260.

16. Tsay, Q. T., Ray, W. H., and Szekely, J., 1976, "The Modeling of Hematite Reduction with Hydrogen Plus Carbon Monoxide Mixtures: Part I. The Behavior of Single Pellets," AIChE Journal, 22(6), pp.1064-1072.

17. Murayama, T., Y. Ono, and Y. Kawai., 1977, "Step-Wise Reduction of Hematite Pellets with CO-CO2 Gas Mixtures," Tetsu-to-Hagané, 63(7), pp.1099-1107.

18. Mills, A.F., 2001. Mass transfer (Vol. 2). Upper Saddle River, NJ, USA: Prentice Hall.

19. Fuller, E.N., Schettler, P.D. and Giddings, J.C., 1966. New method for prediction of binary gas-phase diffusion coefficients. Industrial \& Engineering Chemistry, 58(5), pp.18-27.

20. Fu, D., Chen, Y. and Zhou, C.Q., 2015. Mathematical modeling of blast furnace burden distribution with non-uniform descending speed. Applied Mathematical Modelling. Volume 39, Issues 23-24, pp. 7554-7567.

21. Fu, D., Chen, Y., Zhao, Y., D'Alessio, J., and Zhou, C.Q., 2014. CFD Investigation of the Effects of Iron Ore Reducibility and Coke Reactivity on Blast Furnace Operation, Iron \& Steel Technology, December 2014. pp. 57-64. 